\title{
Akuntansi Sosial: \\ Pengungkapan Sosial (Social Disclosure) dalam Laporan Tahunan
}

Oleh: Drajat Armono, S.E., M.Si

Dosen Program D-3 Fakultas Ekonomi Universitas Islam Indonesia

\section{Abstrak}

Akuntansi sosial difokuskan pada aspek sosial atau dampak (externalities) dari kegiatan pemerintah maupun perusahaan yang justru sering menimbulkan penyakit sosial seperti kerusakan ekosistem, polusi, kriminal, monopoli, keterbelakangan suatu komunitas, meningkatnya utang, diskriminasi sosial, kemiskinan, dan lain-lain. Kurangnya pemahaman aparat maupun manajemen perusahaan terhadap akuntansi sosial, dan biaya penyiapan laporan pertangungjawaban sosial yang relatif besar, serta tidak adanya tuntutan dari masyarakat adalah beberapa faktor yang dapat menunda penerapan akuntansi sosial secara keseluruhan di negeri ini. Tulisan ini mencoba menguraikan beberapa penekanan yang penting bagi pengungkapan sosial (social disclosure) dalam laporan tahunan sebagai wujud akuntabilitas suatu entitas terhadap lingkungan sosialnya. Sedangkan di akhir bagian tulisan ini berisi penutup yang terdiri atas beberapa kesimpulan bagi tercapainya proses pertanggungjawaban tersebut.

\section{A. Pendahuluan}

Penggunaan sumber-sumber ekonomi yang berasal dari masyarakat membuat perusahaan baik secara langsung maupun tidak langsung telah berinteraksi dengan lingkungan sosialnya. Aspek positif dari penggunaan sumber-sumber ekonomi dapat meningkatkan kesejahteraan masyarakat atau yang biasa disebut dengan social benefit. Sementara aspek negatifnya dapat mengurangi kesejahteraan masyarakat atau yang disebut sebagai social cost.

Perkembangan dewasa ini mengarah kepada turitutan pertanggungjawaban sosial perusahaan yang semakin marak dilakukan oleh berbagai pihak yang berkepentingan terhadap hal tersebut. Para stakeholder mulai menekan perusahaan untuk mengungkapkan pertanggungjawaban sosialnya. Pihak yang memiliki kekuatan untuk menekan perusahaan, seperti pemerintah dan badan lainnya mulai mengeluarkan berbagai peraturan mengenai 
Drajat Armono, S.E., M.Si ; Akuntansi Sosial : Pengungkapan Sosial (Social Disclosure) dalam .......

kewajiban perusahaan untuk melaporkan pertanggungjawaban sosialnya. Kalangan perusahaan sendiri pun mulai menyadari pentingnya penjelasan dan pelaporan kepada masyarakat mengenai berbagai upaya dan rencana perusahaan dalam menangani dan melaksanakan tanggungjawab sosial tersebut.

Permasalahan dalam kebanyakan pelaporan sosial dalam akuntansi adalah belum adanya pengukuran yang tepat (valid) pada akibat sosial, yang dikarenakan sulitnya melakukan pengukuran dan pelaporan yang tepat, karena aspek yang diukur mempunyai sifat yang tidak berwujud. Tulisan ini bertujuan untuk mencoba menguraikan beberapa model pengukuran tersebut.

\section{B. Perubahan Paradigma Bisnis}

Laporan keuangan bertujuan untuk mengkomunikasikan informasi yang dihasilkan dari transaksi yang dilakukan oleh perusahaan. Transaksi-transaksi itu pada umumnya berbentuk pertukaran barang dan jasa antara dua entitas ekonomi atau lebih. Secara umum semua transaksi tersebut dapat ter-cover, tetapi ada "cácat" yang bersifat permanen bagi masyarakat secara keseluruhan yaitu méngabaikan pertukaran antara perusahaan dan lingkungan sosialnya. Karena itulah kemudian berkembang konsep akuntansi sosial, yang menurut Belkaoui (1993) konsep ini mengharuskan perusahaan untuk melaporkan interaksi ekonomis dan sosial antara perusahaan dan lingkungannya. Sebagaimana juga diungkapkan oleh Ramanathan (1976), bahwa tujuan perusahaan semata-mata tidak hanya terbatas pada terciptanya laba yang maksimum, melainkan juga mempunyai tanggung jawab terhadap keadaan sosial ekonomi masyarakat secara keseluruhan.

Bagaimanapun juga tidak dapat dipungkiri bahwa perusahaan memperoleh nilai tambah karena adanya kontribusi masyarakat sekitar termasuk lingkungan hayati (social resources). Hal yang perlu dïngat bahwa rusaknya social resources berarti akan menimbulkan social cost yang harus ditanggung oleh masyarakat. Sebaliknya, jika aktivitas perusahaan itu juga bertujuan meningkatkan social resources-nya, maka social benefitlah yang akan diperoleh. Pelaksanaan tanggung jawab sosial perusahaan muncul dari visi manajemen perusahaan, karena visi manajemen perusahaan ke depan mengharuskan adanya pengungkapan informasi tambahan dalam laporan keuangan perusahaan. Tanggung jawab sosial merupakan sesuatu yang berwujud kesadaran untuk mengembalikan sẹbagian manfaat yang diperoleh perusahaan uṇtuk masyạrakat.

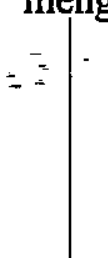




\section{AKuntansi Sosial, Definisi, dan TuJuan}

Pengertian akuntansi sosial menurut Gray (1987) yang dikutip oleh Woodward (1997) adalah sebagai berikut:

Social Accounting - can have two meanings. The first mean the presentation of financial information on the costs and benefits of an organization's social activities. The second, less common meaning is of the regular presentation of a formal social report by the accountable organization.

Dari kutipan tersebut, Gray memiliki dua pengertian akuntansi sosial. Pertama, penyajian informasi keuangan tentang biaya dan manfaat dari aktivitas sosial perusahaan. Kedua, penyajian laporan sosial secara formal sebagai pertanggungjawaban perusahaan. Freedman dalam Siegel dan RamanuskasMarconi (1989) menafsirkan akuntansi sosial yaitu mencoba melihat seberapa jauh perusahaan berdampak pada lingkungan dan seberapa jauh perusahaan mengeluarkan biaya untuk penggantian terhadap dampak-dampak yang ditimbulkan.

Sedangkan Belkaoui (1993) menyebutkan akuntansi sosial sebagai ilmu Socio Economic Accounting (SEA). SEA merupakan ilmu akuntansi yang berfungsi dan mencoba mengidentifikasi, mengukur, menilai, dan melaporkan aspek-aspek social benefit dan social cost yang ditimbulkan oleh suatu lembaga. Pengukuran ini pada akhirnya akan diupayakan sebagai informasi yang dijadikan dasar dalam proses pengambilan keputusan untuk meningkatkan peran lembaga/organisasi/perusahaan, serta untuk meningkatkan kualitas hidup masyarakat dan lingkungan secara keseluruhan.

Ramanathan (1976) mengungkapkan, akuntansi sosial adalah proses seleksi variabel kinerja perusahaan, pengukuran yang dilaksanakan secara sistematis untuk mengembangkan informasi yang berguna bagi evaluasi kinerja sosial perusahaan, dan mengkomunikasikan informasi tersebut kepada kelompok sosial yang bersangkutan di dalam dan di luar perusahaan. Adapun tujuan akuntansi sosial adalah:

1. Mengidentifikasi dan mengukur kontribusi sosial bersih secara periodik suatu perusahaan, yang memasukkan tidak hanya biaya dan manfaat internal perusahaan, tetapi juga manfaat dan biaya yang timbul dari lingkungan perusahaan.

2. Menentukan apakah tindakan dan strategi perusahaan secara individual berpengaruh langsung terhadap sumber daya dan status kemampuan yang relatif dari individu, komunitas, segmen sosial, dan generasi.

3. Membuat tersedianya unsur-unsur pokok sosial, antara lain informasi yang relevan tentang tujuan perusahaan, program, kinerja, dan kontribusi perusahaan pada tujuan sosial secara optimal. 
Drajat Armono, S.E., M.Si ; Akuntansi Sosial : Pengungkapan Sosial (Social Disclosure) dalam

\section{Kelebihan DaN KelemaHan AKUNTANSI Sosial}

Berikut adalah beberapa hal yang berkaitan dengan kelebihan dan kelemahan dari akuntansi sosial.

\section{Kèlebihan}

1. Trotman (1979) yang dikutip oleh Wibisana (1989) berpendapat bahwa dengan adanya pelaporan akuntansi sosial, mampu meperbesar penerimaan atas produk.

2. Mengantisipasi/menghindarkan terjadinya pemogokan ataupun pemboikotan.

3. Menjadi pendongkrak nilai saham (terutama untuk negara-negara dengan struktur keuangan yang kuat).

4. Memberi informasi kepada masyarakat umum tentang sumber-sumber ekonomi yang digunakan.

5. Sebagai parameter sejauh mana atau seberapa jauh kepedulian perusahaan terhadap aktivitas sosialnya.

\section{Kelemahan}

1. Belum adanya pengungkapan dan pengukuran yang tepat pada akuntansi sosial (Wibisana, 1989), yang dikarenakan:

a. Pertanggungjawaban kepada publik hendaknya tidak dicampur adukkan (maupun secara sadar) diintegrasikan dengan pertanggungjawaban kepada kreditur ataupun investor.

b. Pertanggungjawaban kepada kreditur dan investor berwawasan mikro, sedangkan kepada publik berwawasan makro.

c. Pertanggungjawaban kepada kreditur dan investor mengambil sudut pandang pemilik atau perusahaan, sedangkan kepada publik mengambil sudut pandang kepentingan umum atau masyarakat.

2. Tidak adanya suatu kriteria mengenai tingkat kinerja akuntansi sosial perusahaan, yang dikarenakan oleh hal-hal sebagai berikut:

a. Perusahaan mempunyai lebih dari satu pengaruh sosial dalam kegiatan-kegiatannya, sehingga kemungkinan tidak adanya kepraktisan dalam menggunakan satu sistem pengukuran yang berlaku untuk semua pengaruh sosial yang ada.

b. Tidak ada sistem pengukuran yang dapat memecahkan kemungkinan pertentangan yang timbul akibat suatu pengaruh kegiatan perusahaan.

c. Untuk satu aspek umum kinerja sosial, dimungkinkan terdapat adanya sejumlah ukuran alternatif yang dapat dijadikan pertimbangan. 
E. Pengungkapan Akuntansi Sosial

Berikut ini akan penulis ulas untuk beberapa faktor yang mempengaruhi pengungkapan sosial (social disclure).

1. Peraturan Pemerintah

Peraturan pemerintah, baik proses legalisasinya melalui parlemen ataupun dalam bentuk peraturan yang ditetapkan pemerintah, merupakan suatu hal yang sifatnya memaksa. Berkaitan dengan hal tersebut, maka perusahaan mau tidak mau harus mau mengikutinya.

2. Penerapan Standar

Penerapan standar pelaporan dan pengungkapan, khususnya dibidang informasi mengenai tanggung jawab sosial perusahaan oleh berbagai badan pembuat standar akuntansi. Di berbagai negara hal tersebut telah meningkatkan social disclosure perusahaan.

3. Tekanan interest group

Persatuan dagang ataupun serikat pekerja merupakan salah satu contoh interest group yang cukup banyak memberikan tekanan terhadap perusahaan agar mengeluarkan social responsibility disclosure.

4. Kesadaran Perusahaan

Faktor terakhir ini berdasarkan perspektif ekonomi-politik. Perusahaan akan bersikap proaktif terhadap konstituen sosial dan politik. Dengan demikian, perusahaan mengharapkan akan memperoleh image positif dari masyarakat.

Dalam pelaporan sosial secara umum, akuntansi sepertinya belum menghasilkan pengukuran yang tepat (valid) pada akibat sosial. Harus diakui bahwa relatif sulit untuk melakukan pengukuran dan pelaporan yang tepat, karena aspek yang diukur mempunyai sifat yang tidak berwujud. Berikut dipaparkan beberapa pendekatan untuk mengestimasi besarnya manfaat dan biaya sosial. Dalam artikelnya Usmansyah (1989) menyebutkan setidaknya terdapat 3 (tiga) pendekatan yang dapat digunakan sebagai pedoman dalam akuntansi sosial yaitu pendekatan deskriptif, pendekatan biaya, dan pendekatan biaya-manfaat.

- Pendekatan Deskriptif.

Laporan sosial ini mengandung isi uraian mengenai semua kegiatan sosial perusahaan dan merupakan bentuk pelaporan sosial yang paling sederhana dan paling normatif. Laporan sosial deskriptif biasanya digunakan sebagai lampiran laporan keuangan tahunan perusahaan. 
Drajat Armono, S.E., M.Si ; Akuntansi Sosial : Pengungkapan Sosial (Social Disclosure) dalam

- Pendekatan Biaya

Merupakan gambaran semua pengeluaran untuk setiap kegiatan sosial yang dilakukan, dan hal ini merupakan kebalikan dari pendekatan deskriptif. Jika dalam pendekatan deskriptif semua kegiatan diuraikan bukan dalam bentuk satuan mata uang, maka dalam pendekatan biaya semua kegiatan diuraikan dalam bentuk satuan moneter.

- Pendekatan Biaya-Manfaat

Mengungkapkan baik biaya maupun manfaat yang berhubungan dengan kegiatan sosial perusahaan. Pendekatan ini mungkin merupakan pendekatan yang paling informatif dan tepat. Namun dalam kenyataanya sulit untuk diterapkan, dikarenakan kesulitan dalam mengukur manfaat.

Pendekatan lainnya diusulkan oleh Ramanathan (1976), yang menyatakan akuntansi sosial diwujudkan dalam bentuk konsep-konsep transaksi sosial. Konsep-konsep yang diusulkan bagi implementasi social accounting tersebut antara lain:

\section{Social Transaction}

Menggambarkan kegiatan pemanfaatan perusahaan atau pengiriman sumber sosial lingkungan yang berpengaruh secara mutlak atau relatif terhadap berbagai kepentingan unsur-unsur pokok sosial perusahaan dan yang tidak diproses melalui pangsa pasar.

- Social Overheads (returns)

Menggambarkan pengorbanan (manfaat) untuk masyarakat dari penggunaan (penambahan) sumber-sumber daya oleh perusahaan sebagai hasil transaksi sosialnya. Dengan kata lain, social overhead adalah nilai pengukuran atas externalities perusahaan.

\section{- Social Income}

Menggambarkan kontribusi sosial bersih perusahaan secara periodik yang dihitung seperti pada penjumlahan aljabar atas perusahaan yang memakai pengukuran net income, keseluruhan social overheads-nya atau keseluruhan social returns-nya.

- Social Constituents

Adalah pihak-pihak yang mempunyai perbedaan tujuan dengan pihakpihak yang mempunyai kontrak sosial dengan perusahaan.

\section{- Social Equity}

Sebuah pengukuran atas perubahan-perubahan agregat dalam klaim dimana setiap social constituent dianggap sebagai pemilik perusahaan. Ukuran social equity dapat digunakan sebagai dasar pengambilan keputusan sosial dan pengevaluasian kinerja perusahaan. 
- Net Social Asset

Didalam perusahaan hal tersebut adalah sebuah ukuran atas keseluruhan kontribusi non market terhadap kesejahteraan sosial dikurangi dengan deplesi non market dari sumber-sumber sosialnya selama masa hidup perusahaan.

Pendekatan selanjutnya menurut Estes dikutip oleh Seidler dan Seidler (1975: 192), pengungkapan biaya dan manfaat terdiri atas unsur-unsur social benefit dan social cost.

Social Benefits terdiri atas:

- Product and Services Provided

Merupakan kriteria yang menjelaskan bahwa pada umumnya perusahaan berdiri untuk menyediakan produk dan jasa, yang dibeli oleh konsumen dan juga menyediakan bentuk keterangan utama tentang keuntungan untuk masyarakat.

- Payments to Other Elements of Society

Pada kriteria ini mengkonsumsi pemakaian bahan baku sebagai suatu biaya atau kerugian bagi masyarakat, tetapi ketika beberapa bahan baku tersebut telah disediakan setaraf dengan jumlah pembayaran yang diterima. Selanjutnya perusahaan menyumbangkan keuntungan pada bermacam-macam elemen pada masyarakat seperti yang mereka bayar untuk barang dan jasa yang telah digunakan.

- Services employees

Merupakan banyaknya nilai keuntungan golongan yang harus dilaporkan. Jadi harus disediakan program training dan penyediaan kesempatan khusus dalam memberikan penghargaan untuk pekerja.

- Improvement in environment

Kriteria ini terjadi ketika perusahaan memperbaiki area perusahaan, perencanaan penanaman pohon-pohon, pertamanan, serta antisipasi pengikisan tanah dan keterlambatan proses daur ulang.

- Staff services donated to other

Dalam perusahaan nilai keuntungan yang disediakan untuk eksternal organisasi akan lebih rendah daripada kompensasi yang sebenarnya dibayar oleh perusahaan.

- Equipment fasility services donated

Merupakan penjelasan saat perusahaan kadang-kadang mengijinkan kelompok masyarakat untuk menggunakan fasilitas yang kurang baik yang tidak dipakai, dan fasilitas keuntungan yang disediakan tidak ada biaya tambahan bagi perusahaan.

- Other benefit

Dalam hal ini termasuk program semisal pusat pelayanan di hari libur. 
Sedangkan dalam Social Cost kriteria-kriteria yang ada antara lain:

- Human Services Used

Merupakan biaya sosial pada penggunaan jasa manusia yang bagi perusahaan merupakan nilai yang akàn ditimbulkan dalam alternatif penggunaan beberapa jasa. Pengukuran ini menyangkut penerimaan yang akan diterima oleh tenaga kerja, dan ketika hal tersebut terlihat beralasan untuk pengukuran sederhana jasa tenaga kerja, maka jumlahnya diperlihatkan pada bagian laba dan akan dibayar untuk mereka.

- Raw Material Purchased

Merupakan pembelian yang diakui perusahaan sebagai pengorbanan pada masyarakat untuk memperluas nilai mereka dalam penggunaan alternatif.

- Building and Equipment Purchases

Kriteria ini terjadi ketika laporan perusahaan mencantumkan suatu bangunan atau bagian dari suatu peralatan, untuk meyakinkan masyarakat tentang semua bagian yang berguna bagi masyarakat.

- Other Goods and Material Used

Termasuk jenis pencatatan untuk barang-barang seperti: barang-barang milik umum (seperti laut atau sungai), barang-barang yang berharga murah, dan kerusakan atas barang-barang tersebut atau dengan tujuan dihancurkan tanpa melakukan pembayaran.

- Payments from other element of society

Dalam hal ini ada sesuatu yang "dikorbankan", semisal pembeli yang dapat memberikan komentarnya.

- Environment damaged

Dalam kriteria ini perusahaan menentukan daerah atau lingkungan yang nantinya akan terimbas oleh kerusakan yang ditimbulkan oleh aktivitas perusahaan. Kerusakan ini muncul dalam beberapa bentuk, antara lain polusi udara dan air, polusi suara, polusi pemandangan. Dalam pengukuran kerusakan lingkungan, obyeknya adalah nilai estimasi manfaat pada masyarakat untuk aktifitas perusahaan (atau kelalainnya).

- Public Service Used

Kategori ini termasuk bagian pencatatan perusahaan tentang kebijakan lingkungan dalam mendukung sistem legislatif dan peradilan, dan aktifitas perusahaan pada tingkat tertentu.

- Public Fasilities Used

Kategori ini termasuk perusakan pada jalan raya dan jalan kecil, jembatan, taman-taman, bangunan umum, dan kerusakan hayati.

- Work Related Injuries and Illnes

Merupakan biaya yang dapat disebabkan kurangnya eliminasi instalasi pada perencanaan pelayanan dan kondisi yang tidak sehat. Biaya ini 
dapat diestimasi pada nilai jasa yang hilang, kemungkinan menggunakan gaji tenaga kerja dan tingkat upah, ditambah suatu jumlah yang menunjukkan angka pengobatan dan ketidaknyamanan.

- Other Social Cost

Biaya sosial yang tidak biasa dimunculkan dan secara umum tidak pernah 'akan dilaporkan, kecuali laporan keuangan telah dipersiapkan atau diaudit oleh auditor eksternal/auditor independen. Kerugian ini disebabkan oleh penyuapan politik, sabotase oleh pesaing, dan ; pelanggaran lainnya.

\section{F. PENUTUP}

Seperti yang telah disampaikan di awal tulisan ini, bahwa akuntansi sosial difokuskan pada aspek sosial atau dampak (externalities) dari kegiatan pemerintah maupun perusahaan yang justru menimbulkan penyakit sosial seperti kerusakan ekosistem, polusi, kriminal, monopoli, keterbelakangan desa, meningkatnya utang; diskriminasi, kemiskinan, dan lainnya. Dengan jumlah penduduk yang kurang lebih jumlahnya mencapai 220 -an juta jiwa dengan kesejahteraan yang relatif rendah, Indonesia sesungguhnya memerlukan lingkungan hidup yang bebas dari pencemaran lingkungan, paling tidak yang disebabkan kiprah beberapa perusahaan besar yang kurang bertanggung jawab. Gundulnya hutan serta tercemarnya air minum dan pantai, serta kesempatan kerja yang semakin sempit dan tidak seimbang, jarang sekali menimbulkan protes yang begitu menggelora dari sebagian besar masyarakat. Hal tersebut terjadi karena masyarakat tidak mengetahui bahwa betapa besar kerugian yang mereka tanggung. Mungkin mereka tidak sadar akan permasalahan tersebut dan tidak pernah dididik untuk menjadi sadar oleh para pemegang kekuasaan.

Ada beberapa hal yang ada dalam iklim bisnis di Indonesia yang tidak sesuai dengan syarat perkembangan yang ada dalam akuntansi. Contoh kongkrit jika perusahaan pemerintah (seperti PLN, Telkom, Perusahaan Kereta Api, dll) mendapat dana dari masyarakat dan diatur oleh undang-undang, sehingga pengoperasiannya dapat dilakukan atau diambil alih oleh pemerintah. Di sisi lain, pada perusahaan atau perusahaan berbentuk Perseroan Terbatas yang didirikan dengan tidak mendapatkan dana dari masyarakat dan tidak diatur oleh undang-undang, tidak bisa diambil alih secara langsung jalannya operasional perusahaan tersebut oleh pemerintah. Hal ini akan menghambat penerapan akuntansi sosial (Wibisana, 1989). Kurangnya pemahaman aparat manajemen perusahaan terhadap akuntansi sosial, biaya penyiapan laporan tanggung jawab sosial yang relatif besar, serta tidak adanya tuntutan dari masyaraḳat adalah 
Dari beberapa permasalahan yang telah diungkapkan diatas, maka dari analisis penerapan akuntansi sosial terhadap laporan keuangan, dapatlah dikemukakan beberapa saran yang dapat diajukan, yaitu:

1. Ditengah perkembangan bisnis dan ekonomi saat ini, perusahaan diharapkan tetap konsisten dengan visi dan misinya. Tidak hanya sebagai organisasi profit namun juga sebagai agen pembangunan dan mulai merintis penggunaan akuntansi sosial sesuai dengan metode dan kriteria yang ideal.

2. IAI (Ikatan Akuntan Indonesia) sebagai satu-satunya lembaga profesi yang mengatur pengembangan akuntansi di Indonesia, sudah saatnya untuk lebih meningkatkan perhatian pada pengaturan dan pengungkapan tentang penerapan akuntansi sosial dalam laporan keuangan di Indonesia, mengingat fungsinya juga dapat digunakan untuk menentukan kinerja perusahaan.

3. Dalam menerapkan akuntansi sosial sebagai pelengkap laporan keuangan, perlu adanya analisis lebih dalam terhadap pengukuran kinerja yang dihasilkan, sehingga tujuan diterapkannya akuntansi sosial juga tidak , melupakan tujuan perusahaan untuk mencari laba. 
Belkaoui, Ahmad Riahi. (1993). Accounting Theory. Orlando: Harcourt Brace \& Company.

Media Akuntansi. (2000). "Mengulas Kapitalis Menjadi Sosialis". No. 7, Th. I, Maret.

Februari. . (2001). "Pengungkapan Sosial". No. 16, Th. VIII, Januari-

Ramanathan, Kavaseri V. (1976). "Toward a Theory of Corporate Social Accounting". The Accounting Review, (July) p. 516-528.

Seidler, Lee J., and Lynn L. Seidler. (1975). A Comprehensive Corporate Social Reporting Model. Social Accounting: Theory, Issues, and Cases. Los Angeles, Cal.: Melville Publishing Co.

Siegel, Gary, and Helene Ramanauskas-Marconi. (1989). Behavioral Accounting. Cincinati, Ohio: South-Western Publishing Co.

Usmansyah. (1989). "Telaah Alternatif Penerapan Akuntansi Pertanggungjawaban Sosial di Indonesia". Akuntansi, No. 11 Th. VIII, November.

Wibisana, M. Yusuf. (1989). “Akuntansi Sosial: Evaluasi dalam Sejarah Akuntansi”. Media Akuntansi, No. 4, Th. VIII, April.

Woodward, David G. (1997). "A Can of Worms-Some Problems with the Development and Application of the Concept of Corporate Social Reporting". Center for Indonesian Accounting and Management Research, Vol. 5, No. 1. 